\title{
CONCEPTUAL MODEL TO ANALYZE THE INFLUENCE OF CUSTOMER PARTICIPATION AND VALUE CO-CREATION IN SOCIAL MEDIA ON BRAND PERFORMANCE
}

\author{
Taha Nejad Falatouri Moghaddam
}

\begin{abstract}
Brand performance is shown how much a business is successful in the market for profitability and desirability, Value propositions is critical element influencing the brand performance, value proposition can be affected by different aspects of customer experience. In this research, we propose a conceptual model for analysing the level of Customer Participation in social media and value proposition co-creation and the effect of value propositions on brand performance. Social media provides an interactive area for the consumer and business owner to be in touch and to co-create value propositions. Considering this atmosphere, we have offered a conceptual model including Symbolic, Functional, Relational, Emotional, Entitativity and Economical values as possible values which can co-create by the users and business owners on social media. The effect of these values on performance of a brand has been examined as another point. Getting deep into the research literature we faced a new challenge that the behaviour of the different Generation is far from each other then we tried to participate in modern area then we included the generation differentiation into our research by focusing on $\mathrm{Z}$ generation as a mediator variable and other generation on the level of participation on social media for creating value propositions.
\end{abstract}

Keywords: social media, customer participation, value proposition

\section{INTRODUCTION}

The profitability of a business could be prognosticated by its brand performance and the brand performance is in direct relation with the competitive advantage which is contributed to the level of value propositions and customer satisfaction of the service (Rintamäki, Kuusela \& Mitronen, 2007). To creating such values companies can utilize different methods and strategies like product differentiation, agile supply chain, and modern marketing. One of most recent ways is involving customer in creating values through Customer participation for co-creating values. This could be more effective by utilizing new technologies such as social media. This methods and strategies could improve the value proposition while there is controversial question among the scholars how can that these effort improve the values and what trait of value proposition could be influenced by them. To address this question we characterize the values proposition in six different values, by emphasizing on social media activities as the driver of co-creating value proposition we try to understand the level of significance of customer participation on each type of values proposition.

New technologies changed almost in day to day lifestyle, we consecutively face new generation of movements that influenced by technology including retail industries, Retail 4.0 is one the mentioned revolutionary by-products of technology which it is introduced by McKensian company (Desai, Potia \& Salsberg, 2012) according to their definition, Retail 1.0 was related to the time that modern supermarket has been emerged, which was the start of the 20th century. Retail 2.0 was done by the introduction of "everything under one roof," this motto has been advertised by Carefor in 1967. The next step was retail 3.0. The final generation of retail is retail 4.0, the combination of all previous generations. Omnichannel selling or multi-channel 
retail are integral parts of Retail 4.0. This evolution could be described from brick and mortar to click and mortar.

Social Media (SM) is a principal channel that is used in retail 4.0. In 2013 one fourth of world population attended in social media (1.7 billion) (Davis, Piven \& Breazeale, 2014) and nowadays this portion has been raised to over $42 \%$ (Newberry, 2019). Besides, near $20 \%$ of people use social media as a source of news globally (Asher, Caylor \& Neigel, 2018). Along this, SM could radically develop the ability of users to search and surf the internet for analysis and comparison of different services or products (Wang et al., 2019). Moreover, social media create an interactive for the customer and the provider of service to be in touch. These cooperative area has transformed the traditional consumer behaviour and relations, and create higher brand access which develops the strategies of branding under new engagement platform (Davis, Piven \& Breazeale, 2014). Customer participation (CP) as one of the elements of social media has become more and more appealing, where the customer can generate their own content and share it as microblog, comment or any other customer-generated content (CGC).

Industries can use this atmosphere to improve their marketing efforts with lower expenditure, SM makes customer reachable and influence the processes of customer acquisition and retention (Carlson et al., 2018). Previous research has confirmed CP in SM could create different values for the companies brand (Asher, Caylor \& Neigel, 2018), for instance customer could cooperate for Generating new Idea and broadcast it in social media network. This makes a co-creative atmosphere for both customer and business to escalate the brand perception, high level of communication among customers, social networks and retail brand could create astonishing outcomes. Describing customer values is not easy and we cannot find universal definition for it.

In this research we are going to propose a model to analyse how $\mathrm{CP}$ can affect the value proposition and the effect of customer values on brand performance. According to our model the customer participation can change the different type of value proposition while in previous studies many researcher tried to investigate the customer the relation between customer behaviour and value proposition in this research we decide to proceed the customer participation in social media as the critical element factor for creating value proposition.

\section{CONCEPTUAL DEVELOPMENT}

Our theoretical model as described in Figure 1 illustrates the relation among customer values, customer participation and brand performance. In this model we are going to identify the effect of Customer participation on value proposition of customer in Symbolic, Functional, Relational, Emotional, Entitativity and Economical values. In consequence, we want to extract the effect of these values on Brand performance. To analyse the brand performance status we have to consider generation type to justify the generation role on customer participation and its effects.

\subsection{CP in Social media}

The value propositions are not consuming by the consumption of products, they are experienced through a process of purchasing and consuming. The creation of value is an individual experience which is happening along a series of activities such as building relationships, active communication and knowledge gathering. In the retail industry the whole procedure is more in-depth while the customer gain these values in the "life world". It means each step of the customer experience from purchasing to using and sharing the feedbacks shapes their values propositions of product or service (Carlson et al., 2019). 


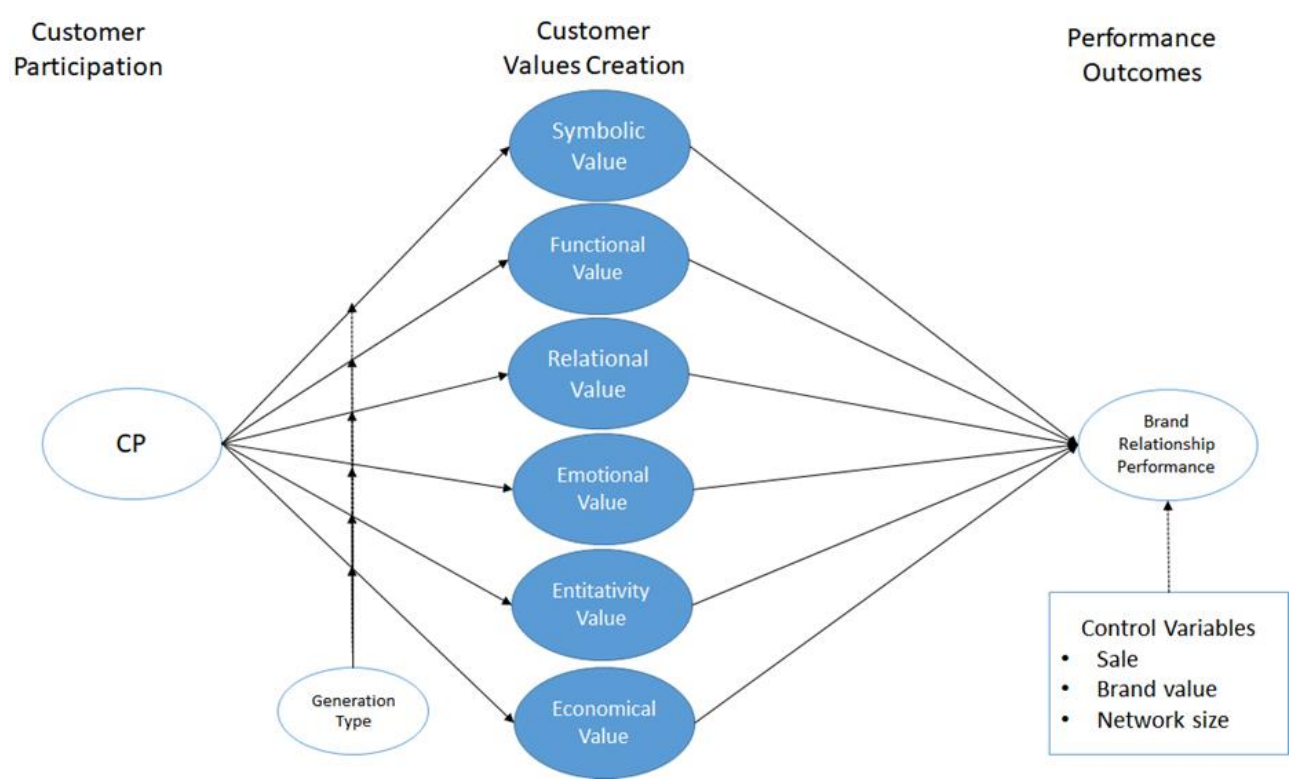

Fig. 1 - Conceptual Development Model. Source: own research

Finally the level of inter personal attraction of social media pages which can make a substantial foundation for connecting the current and optional customer this variable is under control of both individuals and companies. And both groups can help take part in it. Symbolic value is the self-expressive of customer consumption (Word of mouth) (Suryadi et al., 2018). Functional benefits is coming from higher quality that has been expected by the customer. Emotional value is related to the fun and enjoyment part of customer experience. Relational value is the benefit of meaningful relationship between customer and the service provider. Entativity value is associated with the sense of belonging to a brand (Carlson et al., 2019) and finally the economic value is related to the price. In SM all these values could be analysed during the degree of interactivity and participating in such area (Carlson et al., 2019).

According to what is mentioned in the introduction part our proposed model is analysing the level of customer participation in social media and it impacts on value propositions. In order to find out the level customer participation in social media we extract different variable from the literature and clustered them into three groups first group of variable are personal variable this group of variable are under control by the individuals or customer who are attending in the social media page of companies: "time" amount of time allocating on activities is a good measure for showing the level of participation "Sharing" idea, posts, mini-blog and hashtags is another measure that can be counted as an active participation another essential variable is "personal characteristic" while many attendance of social media are not sharing their own characteristic and level of disclosure could show the loyalty, many people attend on social media to waste their time or as a personal habit but "helping" other customer and measure as a valid participation. The second group of variable are under control by the company and they are relating to the level of entertaining of the social media page from the point of users it is worth to mention that this variable can radically improves the number of attendance of the social media page.

\section{HYPOTHESES DEVELOPMENT}

Effect of CP on Symbolic values: Participating in social media can be obviously related to symbolic values where the customer can broadcast their purchasing and commitment to the brand on SM. 


\section{H1: Higher level of CP could lead to more symbolic values}

Effect of CP on Functional values: According to (Davis, Piven \& Breazeale, 2014) the customers usually attend in Social media of a brand for 1-solving some problems 2- sending inquiries 3- searching for brand information 4-analysing offers before purchase 5- to find out the brand's exclusive deals. Moreover, customers in social media can provide information and contact with the developers of the service to gain more functionality values across the production offers or feedbacks.

H2: Higher level of CP could lead to more functional value

Effect of CP on relational values: SM could connect the providers and the consumer without boundaries of location, individuals can have a customized relation to the brand owner and feel the sense of engagement in the brand strategies.

\section{H3: Higher level of CP could lead to more relational value}

Effect of CP on emotional values: Participating in brand strategies and development of product could increase the enjoyment relating to service and final outcomes. SM can quickly provide these interactive areas for both sides.

\section{H4: Higher level of CP could lead to more emotional values}

Effect of CP on entitativity values: This value is describing in the situation where all people are considered as one individual. In this case people share their idea not only for their own goals but also for the benefit of others. SM can provide this area in different ways from sharing their personal experiences to help others.

\section{H5: Higher level of CP could lead to more entitativity values}

Effect of CP on economical values: As it is mentioned in the introduction part of this article, people use SM to find out the best quality and best price for their needs. In other words, one of the main reasons for participating in SM is Economical value.

H6: Higher level of CP could lead to more economical values

\subsection{The moderating role of generation on $\mathrm{CP}$}

According to X, Y and Z generation (Betz, 2019) the generation X is better educated than their previous generations and more concerned in ethics and they are less engaging in technological affair. Generation Y as it is most well-known with the name Millennial Generation, faced with technology in their youngster age compared to their previous generation. They are not technology immigrants, they grow up with technology and near $80 \%$ of this generation are using smartphone, Y generation are calling digital natives. Finally Generation $\mathrm{Z}$ is the multitasking generation where they use technology while doing other activities simultaneously, this generation learn actively and has grown up in the internet world and their understandings of information system is different from their ancestors. Relating to these differences the generation attitudes towards $\mathrm{CP}$ is different and may be varied radically. To analyse these differences, we provide different hypothesis for the $\mathrm{Z}$ Generation where we guess they have a better understanding of $\mathrm{CP}$ and $\mathrm{SM}$ in many aspects to analyse the impacts.

H7a: The relationship between CP and Symbolic value is stronger in $Z$ generation

H7b: The relationship between CP and Functional value is stronger in $Z$ generation

$H 7 c$ : The relationship between $C P$ and Relational value is stronger in $Z$ generation

H7d: The relationship between $C P$ and Emotional value is stronger in $Z$ generation 
H7e: The relationship between $C P$ and Entitativity value is stronger in $Z$ generation

$H 7 f:$ The relationship between $C P$ and Economical value is stronger in $Z$ generation

Control variables: To test our hypothesis in robust framework we used three control variables: sale, Brand value and network size to be sure that the results are note due to covariance with other variables.

\section{MEASURING ITEMS}

In order to analyse the idea we have to assess the sample opinion in the following items which comes in Table 1.

Tab. 1 - The measurement items of the concept. Source: own research

\begin{tabular}{|c|c|}
\hline $\begin{array}{l}\text { First-order } \\
\text { constructs }\end{array}$ & Measurement items \\
\hline \multirow{8}{*}{$\begin{array}{l}\text { Customer } \\
\text { Participation }\end{array}$} & I spent a lot of time in my favorite brand social media \\
\hline & I always express my need on my favorite brand social media \\
\hline & I share my personal character on my favorite brand social media \\
\hline & I have active participation in my favorite brand social media \\
\hline & I always share my idea on my favorite brand social media \\
\hline & I always help other people to find out information about my favorite brand on social media \\
\hline & I always share my feedback on my favorite brand social media \\
\hline & I always share suggestions to improve my favorite brand social media page \\
\hline Symbolic value & I always share my new purchases of my favorite brand on social media \\
\hline \multirow{3}{*}{ Functional Value } & My favorite brand social media is helpful for me \\
\hline & My favorite brand social media is useful for me \\
\hline & My favorite brand social media is functional for me \\
\hline \multirow{3}{*}{ Emotional Value } & My favorite brand social media is funny \\
\hline & My favorite brand social media is exciting \\
\hline & My favorite brand social media is entertaining \\
\hline \multirow{2}{*}{ Relational Value } & $\begin{array}{l}\text { My participation in social media of my favorite brand could help me make a better connection with } \\
\text { other people }\end{array}$ \\
\hline & $\begin{array}{l}\text { My participation in social media of my favorite brand could make long term connection with my } \\
\text { favorite brand }\end{array}$ \\
\hline \multirow[t]{3}{*}{ Entitativity Value } & I feel like a family member in my favorite brand social media member \\
\hline & $\begin{array}{l}\text { I feel like a member of the organization of my favorite brand when I am participating in their social } \\
\text { media }\end{array}$ \\
\hline & I am satisfied with social media of my favorite brand \\
\hline Economical value & I am supporting the pricing strategies of my favorite brand on social media \\
\hline
\end{tabular}

\section{CONCLUSION}

In this research we have proposed a conceptual model to analyse the effect of customer participation in social media on value proposition. We have extract the relations among the variables trough personal, companies and cooperative values y considering the impact of moderating variable of generation. We expect that the best method for analysing the idea in this methodology would be structural equation and the means for data gathering would be questionnaire among the attendance of public page of social media of prestige brand that is planned to be down in the future research participation in social media on value proposition. Presence of public page of social media of prestige brands that is designed to be down in the future research. 


\section{References}

Asher, D. E., Caylor, J. P., \& Neigel, A. R. (2018). Effects of Social Media Involvement, Context, and Data-Type on Opinion Formation. 2018 International Workshop on Social Sensing (SocialSens), 32-37. doi: 10.1109/socialsens.2018.00019

Betz, C. L. (2019). Generations X, Y, and Z. Journal of Pediatric Nursing, 44, A7-A8. doi: 10.1016/j.pedn.2018.12.013

Carlson, J., Rahman, M., Voola, R., \& De Vries, N. (2018). Customer engagement behaviors in social media: Capturing innovation opportunities. Journal of Services Marketing, 32(1), 83-94. doi: 10.1108/JSM-02-2017-0059

Carlson, J., Wyllie, J., Rahman, M. M., \& Voola, R. (2019). Enhancing brand relationship performance through customer participation and value creation in social media brand communities. Journal of Retailing and Consumer Services, 50, 333-341. doi: 10.1016/j.jretconser.2018.07.008

Davis, R., Piven, I., \& Breazeale, M. (2014). Conceptualizing the brand in social media community: The five sources model. Journal of Retailing and Consumer Services, 21(4), 468-481. doi: 10.1016/j.jretconser.2014.03.006

Desai, P., Potia, A., \& Salsberg, B. (2012). Retail 4.0: The future of retail grocery in a digital world. Retrieved from https://www.sipotra.it/wp-content/uploads/2017/06/The-futureof-retail-grocery-in-a-digital-world.pdf

Newberry, C. (2019). 130+ social media statistics that matter to marketers in 2019. Retrieved from https://blog.hootsuite.com/social-media-statistics-for-social-media-managers/

Rintamäki, T., Kuusela, H., \& Mitronen, L. (2007). Identifying competitive customer value propositions in retailing. Managing Service Quality: An International Journal, 17(6), 621-634. doi: 10.1108/09604520710834975

Suryadi, N., Suryana, Y., Komaladewi, R., \& Sari, D. (2018). Consumer, customer and perceived value: Past and present. Academy of Strategic Management Journal, 17(4), 19. Retrieved from https://search.proquest.com/docview/2124080569?accountid=15518

Wang, Y., Chowdhury Ahmed, S., Deng, S., \& Wang, H. (2019). Success of social media marketing efforts in retaining sustainable online consumers: An empirical analysis on the online fashion retail market. Sustainability, 11(13), 3596. doi: 10.3390/su11133596

\section{Contact information}

\section{Taha Nejad Falatouri Moghaddam}

Tomas Bata University in Zlín, Faculty of Management and Economics

Mostní 5139, 76001, Zlín, Czech Republic

E-mail: Falatouri_moghaddam@utb.cz

ORCID: 0000-0001-9586-3180

doi: 10.7441/dokbat.2019.075 